\title{
MODEL KOMUNIKASI FORMAL DAN INFORMAL DALAM PROSES KEGIATAN PEMBERDAYAAN MASYARAKAT
}

\author{
Adhi Iman Sulaiman \\ Fakultas Ilmu Sosial Ilmu Pemerintahan Universitas Jenderal Soedirman \\ Jl. Prof. Dr. Boenyamin No 993 Purwokerto- 53122, Jawa Tengah, HP. 081572222267 \\ Email:adhi_iman@yahoo.com \\ Naskah diterima tanggal 17 Oktober 2013 - disetujui tanggal 14 November 2013

\section{FORMAL AND INFORMAL COMMUNICATION MODEL ACTIVITY IN THE PROCESS OF EMPOWERMENT}

\begin{abstract}
Abstact
The research development actors are performing on the communication functions. In this study focused on the formal and informal communication, as of opening access, approach on location, design, implementation and evaluation of empowerment program, located in the village of Pasuruhan, Subdistrict Binangun of Cilacap Regency. The purpose of this study was to construct patterns of formal and informal communication in the process of community development activities, especially in the village of Pasuruhan, District Binangun, Cilacap Regency, Central Java Province. The approach was qualitative and the study sample was purposive. Data collection techniques with the Focus Group Discussion (FGD), interviews and observations. Results showed: (1) Formal communication could not be separated from the formal communication in the research process and implementation of empowerment. While formal communication performed after the open access and to reinforce the aim of activity. And then in the implementation of socialization, extension and comparative studies. (2) The failure to informal communication processes, maked the process of qualitative research in particular, could be resistance, minus support, distrust, and could even rejection of research informants. (3) Formal communication had structured nature, focused and symbolic interaction of status the institution or organization of communicators. While the informal communication had unstructured nature, dialogical process or more flexible and could be long term, however the discussion would be not focus.
\end{abstract}

Keywords: formal communication, informal communication, community empowerment.

\begin{abstract}
Abstrak
Penelitian ini mengenai fungsi komunikasi yang diperankan oleh para pelaku pembangunan, pada kegiatan pemberdayaan masyarakat. Fokus penelitian adalah bentuk komunikasi formal dan informal, yang berlokasi di Desa Pasuruhan Kecamatan Binangun Kabupaten Cilacap. Tujuan penelitian ini untuk mengonstruksi pola komunikasi baik formal maupun informal dalam proses kegiatan pemberdayaan masyarakat khususnya di Desa Pasuruhan, Kecamatan Binangun, Kabupaten Cilacap, Provinsi Jawa Tengah. Pendekatan penelitian adalah kualitatif dan pengambilan sampel penelitian adalah purposif. Teknik pengumpulan data dengan Focus Group Discussion (FGD), wawancara, dan observasi, kemudian menggunakan analisis data interaktif. Hasil penelitian menunjukkan bahwa (1) Komunikasi formal tidak bisa dipisahkan dari
\end{abstract}


komunikasi informal dalam proses penelitian dan pelaksanaan pemberdayaan. Komunikasi formal dilakukan setelah akses terbuka dan untuk mempertegas suatu tujuan kegiatan. Kemudian dalam pelaksanaan kegiatan sosialisasi, penyuluhan, dan studi banding. (2) Kegagalan proses komunikasi informal, mengakibatkan resistensi, kurang mendapat dukungan, timbul kecurigaan, bahkan bisa terjadi penolakan dari informan penelitian. (3) Komunikasi formal memiliki sifat terstruktur, terfokus, dan adanya interaksi simbol atas nama status institusi atau lembaga dari para pelaku komunikasi. Sedangkan komunikasi informal sifatnya tidak terstruktur, proses dialog lebih bebas atau tidak kaku yang bisa berlangsung lama, walaupun pembahasan bisa saja tidak fokus. Interaksi mengutamakan keakraban atau menjalin hubungan yang intens.

Kata kunci: komunikasi formal, komunikasi informal, pemberdayaan masyarakat.

\section{PENDAHULUAN}

Pemberdayaan masyarakat sebagai proses pembangunan yang menitikberatkan pada identifikasi masalah yang dihadapi dan potensi yang dimiliki baik sumberdaya manusia (kompetensi) maupun sumberdaya material dengan diberikan ruang atau kesempatan supaya dapat mengembangkan diri atau dikembangkan menuju kemandirian ke arah perubahan yang lebih baik. Menurut Payne (1997) bahwa pemberdayaan adalah “ to help clients gain power of decision and action over their own lives by reducing the effect of social or personal blocks to exercising existing power, by increasing capacity and self confidence to use power and by transferring power from the environment to clients".

Jadi pemberdayaan membahas bagaimana individu, kelompok, atau komunitas berusaha mengontrol kehidupan mereka sendiri dan mengusahakan untuk membentuk masa depan sesuai dengan keinginan mereka. Begitupun menurut Syahyuti (2006) bahwa salah satu yang esensial dalam pemberdayaan adalah ketika individu atau masyarakat diberikan kesempatan untuk membicarakan apa yang dianggap penting untuk perubahan yang mereka butuhkan.

Terdapat fungsi komunikasi yang diperankan oleh pelaku pemberdayaan yang diindikasikan dalam suatu dialog atau komunikasi yang partisipatif antar masyarakat untuk mengontrol dan menentukan kehidupannya mulai dari proses perencanaan, pelaksanaan, dan evaluasi dalam pembangunan. Sebagaimana dikatakan Lubis (2010), bahwa pada saat ini, pembangunan banyak mempergunakan pendekatan partispatif yang melibatkan seluruh warga, yaitu dari sejak tahapan perencanaan, pelaksanaan, evaluasi sampai ke tahapan menikmati hasil pembangunan. Pada pendekatan ini, proses komunikasi memegang peranan yang sangat penting, karena melalui proses komunikasi, partisipasi tersebut dapat terwujud.

Pentingnya fungsi komunikasi dalam proses pembangunan melalui kegiatan pemberdayaan ditegaskan dari hasil penelitian dari Muchlis (2009) yang menegaskan pentingnya komunikasi yang bersifat partisipatif dalam program pemberdayaan masyarakat, sehingga dapat mengakomodir keberagaman ekonomi, sosial, agama, dan faktor budaya serta gender. Kemudian hasil penelitian dari Satriani (2011) bahwa dampak komunikasi partisipatif dalam setiap kegiatan masyarakat dan rapat sangat bermanfaat dengan saling berbagi informasi dan pengetahuan, penyelesaian masalah diselesaikan secara bersama serta terjalinnya keakraban sesama.

Komunikasi yang dilakukan dalam pembangunan seperti pada proses pemberdayaan, berlangsung dalam bentuk komunikasi secara formal, seperti pada rapat, musyawarah atau saresehan antarpelaku pemberdayaan. Termasuk bentuk komunikasi informal yang tidak dapat dipisahkan ketika proses komunikasi formal akan, sedang, dan telah berlangsung, yaitu melalui lobi dan negosisasi. Sebagaimana menurut Verdeber dalam Mulyana (2005), bahwa komunikasi 
memiliki dua fungsi umum yaitu fungsi sosial untuk kelangsungan memelihara hubungan bersama, dan fungsi pengambilan keputusan.

Maka sangat menarik penelitian mengenai fungsi komunikasi, dalam hal ini memfokuskan pada komunikasi formal dan informal ketika proses kegiatan pemberdayaan masyarakat di Desa Pasuruhan, Kecamatan Binangun, Kabupaten Cilacap, Provinsi Jawa Tengah sebagai lokasi penelitian. Pertimbangan menentukan lokasi penelitian tersebut berdasarkan hasil penelitian Suswanto (2011) bahwa (1) Lokasi tersebut sangat menarik perhatian atau menjadi sorotan publik baik nasional maupun internasional, yaitu terjadinya tiga kali peristiwa penangkapan yang diduga teroris pada tahun 2009. (2) Masyarakat di Desa Pasuruhan, masih merasa traumatik atas peristiwa tersebut, sehingga perlu mendapat pendekatan yang lebih humanistik melalui kegiatan pembauran dan harmonisasi dalam proses pemberdayaan masyarakat. (3) Penulis merasa tertarik meneliti proses komunikasi formal dan informal dalam kegiatan pemberdayaan masyarakat, karena selama ini luput dari amatan dan kajian penulis. Padahal komunikasi sangat penting serta strategis fungsinya dalam proses kegiatan seperti pemberdayaan masyarakat yang diperankan oleh penulis, penyuluh, atau instruktur dan para peserta.

Berdasarkan hal tersebut, dapat ditarik suatu permasalahan dalam penelitian ini yaitu Bagaimana komunikasi formal dan informal dalam proses kegiatan pemberdayaan di Desa Pasuruhan, Kecamatan Binangun, Kabupaten Cilacap, Provinsi Jawa Tengah?

Sehingga penelitian ini bertujuan untuk mengonstruksi pola komunikasi baik formal maupun informal dalam proses kegiatan pemberdayaan masyarakat khususnya di Desa Pasuruhan, Kecamatan Binangun, Kabupaten Cilacap, Provinsi Jawa Tengah. Kemudian hasil penelitian ini dapat lebih memberikan perhatian pada kajian komunikasi yang sangat penting dan strategis dalam suatu proses kegiatan seperti pemberdayaan masyarakat. Karena suatu kegiatan seperti pemberdayaan masyarakat bagi penulis bukan hanya hasil kegiatan, tetapi penting juga mengkaji dari proses kegiatannnya yaitu fungsi komunikasi yang diperankan oleh penulis, penyuluh, atau instruktur dan peserta kegiatan. Manfaat, problematika, dan hambatan kegiatan, juga bisa teridentifikasi serta mendapat solusi dengan meneliti (menganalisis) proses kegiatan melalui kajian komunikasi.

\section{LANDASAN KONSEP}

\section{Pemberdayaan Masyarakat}

Hakikat pemberdayaan sebagaimana telah dibahas dalam pendahuluan, adalah suatu usaha menyinergikan kekuatan (potensi dan sumberdaya) yang dimiliki, kesempatan (yang diciptakan dan diberikan) menuju kemandirian dan perubahan yang lebih baik.

Maka dalam pemberdayaan terdapat pelaku perubahan, yang melakukan sesuatu terhadap klien (pelaku pemberdayaan) baik pada tingkat individu, keluarga, kelompok ataupun komunitas. Pemberdayaan adalah upaya memberdayakan atau mengembangkan klien dari keadaan yang tidak atau kurang berdaya menjadi mempunyai daya guna mencapai kehidupan yang lebih baik. Berkaitan dengan hal tersebut Shardlow dalam Adi (2003) mengatakan bahwa "such a definition of powerment is centrally about people control of their own lives and having the power to shape their own future". Jadi pemberdayaan pada intinya membahas bagaimana individu, kelompok, ataupun komunitas berusaha mengontrol kehidupan mereka sendiri dan mengusahakan untuk membentuk masa depan sesuai dengan keinginan mereka.

Konsep pemberdayaan merupakan proses belajar hingga mencapai status mandiri. Meskipun demikian dalam rangka menjaga kemandirian tersebut tetap dilakukan pemeliharaan semangat, kondisi, dan kemampuan secara terus menerus supaya tidak mengalami kemunduran lagi. Tahaptahap yang harus dilakukan dalam pemberdayaan adalah: Pertama, tahap penyadaran dan pembentukan perilaku menuju perilaku sadar dan peduli sehingga merasa membutuhkan peningkatan kapasitas 
diri. Kedua, tahap transformasi kemampuan berupa wawasan pengetahuan, kecakapan, keterampilan agar terbuka wawasan dan memberikan keterampilan dasar sehingga dapat mengambil peran di dalam pembangunan. Ketiga, tahap peningkatan kemampuan intelektual, kecakapan, dan keterampilan sehingga terbentuklah inisiatif dan kemampuan inovatif untuk mengantarkan pada kemandirian (Sulistiyani, 2004).

Terdapat fungsi komunikasi yang sangat penting dan strategis dalam proses pelaksanaan pemberdayaan yang melibatkan dialog partisipatif antara pemangku kepentingan, dengan masyarakat secara umum (civil society) mulai dari perencanaan, pelaksanaan, pengawasan, dan evaluasi. Sebagaimana menurut Syahyuti (2006) bahwa salah satu yang esensial dalam pemberdayaan adalah ketika individu atau masyarakat diberikan kesempatan untuk membicarakan apa yang dianggap penting untuk perubahan yang mereka butuhkan.

Lebih lanjut Mardikanto (2010) secara komprehensif menjelaskan tentang fungsi pemberdayaan yang pada intinya sebagai berikut: (1) Pemberdayaan sebagai proses perubahan; (2) Pemberdayaan sebagai proses pembelajaran; (3) Pemberdayaan sebagai penguatan kapasitas: (i) Penguatan kapasitas individu, (ii) Penguatan kapasitas entitas (kelembagaan), dan (iii) Penguatan kapasitas sistem (jejaring); (4) Pemberdayaan sebagai proses perubahan sosial; (5) Pemberdayaan sebagai proses pembangunan masyarakat; (6) Pemberdayaan sebagai proses pengembangan partisipasi masyarakat.

\section{Fungsi Komunikasi dalam Pembangunan melalui Pemberdayaan}

Konsep klasik yang masih relevan menyangkut fungsi komunikasi dalam proses pembangunan, yaitu menurut Schramm dalam Nasution (2009) yang merumuskan tugas pokok komunikasi dalam suatu perubahan sosial dalam rangka pembangunan nasional yaitu: (1) Menyampaikan kepada masyarakat, informasi tentang pembangunan nasional, agar mereka memusatkan perhatian pada kebutuhan akan perubahan, kesempatan dan cara mengadakan perubahan, sarana-sarana perubahan dan membangkitkan aspirasi nasional. (2) Memberikan kesempatan kepada masyarakat untuk mengambil bagian secara aktif dalam proses pembuatan keputusan, memperluas dialog agar melibatkan semua pihak yang membuat keputusan mengenai perubahan, memberi kesempatan kepada para pemimpin masyarakat untuk memimpin dan mendengarkan pendapat rakyat kecil, dan menciptakan arus informasi yang berjalan lancar dari bawah ke atas.

Komunikasi untuk pembangunan yang menghasilkan partisipasi, dialog, dan penyebaran pengetahuan penting. Komunikasi juga dapat membantu pembangunan dengan mendukung dan mengadopsi model yang benar-benar membutuhkan dialog dari kolaborasi antara semua pemangku kepentingan dan yang benar-benar membutuhkan berbagi pengetahuan sebagai bentuk terbaik dari pendidikan bersama. Hal ini dikemukakan oleh Mefalopulos dalam Dasgipta (2009) bahwa "communication for development is motivated towards generating participation, dialogue, and dissemination of vital knowledge. Communications can assist development by advocating and adopting models that genuinely require dialogue as a from of collaboration among all stakeholders and that genuinely require sharing knowledge as the best form of mutual education".

Maka dengan fungsi komunikasi partispatif dan dialogis yang dibutuhkan dalam proses pemberdayaan, menjadikan paradigma pembangunan telah bergeser dari yang ditentukan oleh elit penguasa kepada publik (civil society) yang bersifat top down menjadi bersifat bottom up artinya publik juga ikut menentukan (berpartisipasi). Sebagaimana pendapat Rangkuti (2011) bahwa paradigma pembangunan saat ini mengalami pergeseran di mana pembangunan menekankan pada pemberdayaan (empowerment) yang dikenal dengan pembangunan manusia (people centered development), pembangunan berbasis sumber daya lokal (resource based development), dan pembangunan kelembagaan (institutional development). 


\section{Komunikasi Formal dan Informal}

Komunikasi formal dan informal sebagai suatu sinergi dikemukakan oleh Effendy (2005) bahwa sistem komunikasi formal biasanya mengikuti garis-garis wewenang sebagaimana dituangkan dalam struktur organisasi (organigram). Sedangkan sistem informal (tidak formal) adanya hubungan-hubungan sosial yang dapat memiliki kekuatan untuk menentukan wewenang yang ditransmisikan melalui sistem formal tersebut dapat diterima. Sehingga sangat penting posisi wewenang di dalam sistem formal maupun informal.

Pertama, Komunikasi formal. Komunikasi formal, menurut Mulyana (2005) adalah komunikasi menurut struktur organisasi seperti komunikasi ke bawah dan komunikasi ke atas, dan komunikasi horisontal. Kemudian menurut Blake dan Haroldsen (2005) ciri komunikasi organisasi dan saluran formal banyak persamaan. Ciri saluran komunikasi formal menurut Shibutani dalam Blake dan Haroldsen (2005) yaitu: (1) saluran komunikasi berfungsi dengan standar bagi semua laporan yang datang dari berbagai sumber agar dapat diperiksa kebenarannya. (2) sumber pesan dapat dikenali dan tentunya dapat dipercaya. Sehingga dapat dijelaskan saluran komunikasi formal bercirikan aturanaturan yang stabil, pekerjaannya, aturan, dan sanksi disusun dengan jelas, serta dapat diikuti oleh orang-orang yang berbeda. Peserta dapat dikenali dan dapat dipercaya serta bertanggung jawab serta ada jalur komunikasi yang akurat.

Kedua, Komunikasi informal. Menurut Mulyana (2005) komunikasi informal tidak tergantung pada struktur organisasi. Kemudian DeVito (2011) komunikasi informal sebagai komunikasi yang disetujui secara sosial yang orientasinya tidak pada organisasi tetapi lebih secara individual.

\section{Kerangka Pemikiran}

Dalam penelitian ini menggunakan konsep atau model komunikasi sebagai kerangka pemikiran mengenai komunikasi yang dipergunakan dan relevan dengan penelitian ini, West dan Turner (2008) yaitu:
Pertama, komunikasi sebagai interaksi (model interaksional), yang menekankan proses komunikasi dua arah di antara para komunikator, terdapat umpan balik (feedback) atau tanggapan terhadap suatu pesan yang bisa berupa verbal dan nonverbal, sengaja maupun tidak disengaja sebagai pertukaran makna. Kedua, komunikasi sebagai transaksional (model transaksional) prosesnya bersifat kooperatif di mana pengirim dan penerima sama-sama bertanggung jawab terhadap dampak dan efektivitas komunikasi yang terjadi serta aktif untuk membangun kesamaan makna (pemahaman) secara simultan (terus-menerus) menerima dan mengirim pesan secara verbal dan nonverbal.

Landasan komunikasi interaksional relevan dengan teori komunikasi model ketiga dari Schramm dalam Mulyana (2005) menganggap komunikasi sebagai interaksi dengan kedua pihak yang menyandi, menafsirkan, menyandi balik, menransmisikan dan menerima sinyal. Sedangkan landasan teori Komunikasi Transaksional relevan dengan teori Komunikasi Konvergensi dari Rogers dan Kincaid (1981) bahwa komunikasi sebagai sebuah proses di mana para partisipan membuat dan berbagi informasi dengan satu sama lain untuk mencapai saling pengertian.

\section{METODE PENELITIAN}

Penelitian yang dirancang adalah penelitian kualitatif yang sangat cocok untuk mengonstruksi pola komunikasi formal dan informal yang terjadi dalam proses kegiatan pemberdayaan masyarakat. Sebagaimana menurut Bogdan dan Taylor (1993) bahwa metode kualitatif memungkinkan untuk memahami masyarakat secara personal atau kelompok yang mengungkap pandangan dunianya dari pengalaman-pengalaman di dalam masyarakat yang belum diketahui. Kemudaian menurut Denzin dan Lincoln (2009) bahwa metode kualitatif yang mempelajari segala sesuatu di dalam konteks alaminya, untuk memahami atau menafsirkan fenomena dari makna yang melekat pada manusia atau peneliti. 
Penelitian kualitatif yang dipergunakan adalah studi kasus, seperti menurut Azis (2008) bahwa jenis penelitian yang utama melalui pendekatan kualitatif dalam penelitian sosial, salah satunya adalah dengan menggunakan studi kasus sebagai penelitian yang terinci tentang individu atau suatu unit sosial selama kurun waktu tertentu secara mendalam.

Teknik penentuan informan adalah purposif, artinya pemilihan informan berdasarkan pertimbangan rasional penulis bahwa informan tertentu yang memiliki kompetensi untuk memberikan informasi atau data yang diharapkan penulis. Sebagaimana menurut Herdiansyah (2011) purposif sampling digunakan penulis untuk memilih subjek penelitian dan lokasi penelitian dengan tujuan untuk mempelajari dan memahami permasalahan serta tujuan penelitian. Informan kunci dalam penelitian ini yaitu KK sebagai mahasiswa Universitas Terbuka dan WS sebagai Kepala Desa Pasuruhan Kecamatan Binangun Kabupaten Cilacap. Adapun informan sebagai subjek penelitian dan peserta pemberdayaan yang berasal dari kelompok usaha, yaitu: (1) Koperasi Syariah Abdimas Sejahtera: (i) KDS, (ii) DSM, (iii) K, dan (iv) Aris AW. (2) KUKM: (i) W, (ii) S, (iii) DAN, dan (iv) MS, (v) S, (vi) K dan (vii) R. (3) Kelompok tani yaitu (i) D, (ii) YS, (iii) $\mathrm{PH}$, (iv) S. Objek penelitiannya adalah model komunikasi formal dan informal dalam proses pemberdayaan masyarakat.

Teknik pengumpulan data yang digunakan untuk penelitian pada komunikasi formal dilakukan proses Focus Group Discussion (FGD). Menurut Kriyantono (2006) metode FGD yaitu sebagai teknik pengumpulan data untuk memahami sikap dan perilaku khalayak serta diskusi yang tidak terstruktur dengan topik yang dipersiapkan. Adapun hal yang harus dipertimbangkan dalam FGD, yaitu: (1) Tidak ada jawaban yang benar atau salah setiap orang peserta FGD harus merasa bebas untuk menjawab sesuai dengan permasalahan diskusi. (2) segala interaksi dan perbincangan harus terekam dengan baik. (3) diskusi harus berjalan dengan suasana informal, sehingga peserta dapat memberikan komentar (antusias-aktif) sekalipun tidak ditanya langsung sehingga terjadi tukar pendapat secara dinamis.

Selanjutnya untuk penelitian pada komunikasi informal dilakukan metode wawancara tidak terstruktur dan observasi atau pengamatan secara langsung di lapangan. Metode pengumpulan data dengan teknik wawancara dan observasi juga dilakukan secara berbarengan ketika proses metode FGD pada penelitian komunikasi secara formal. Sehingga dalam proses penelitian kualitatif pada kasus ini, ketiga metode tersebut saling melengkapi.

Analisis data yang dipergunakan yaitu analisis data interaktif dari Miles dan Huberman (2007) yang terdiri dari tiga komponen: (1) Reduksi data, yang merupakan proses pemilihan, pemusatan, penyederhanaan dan klasifikasi data mentah yang muncul dari catatan-catatan tertulis di lapangan, yang berlangsung secara terusmenerus selama penelitian. (2) Penyajian data adalah kumpulan informasi yang tersusun yang memberi kemungkinan adanya penarikan kesimpulan dan pengambilan tindakan. (3) Penarikan kesimpulan atau verifikasi.

\section{HASIL PENELITIAN DAN PEMBAHASAN}

\section{Hasil Penelitian \\ Komunikasi Formal dan Informal dalam Proses Pembukaan Akses}

Proses penelitian, terutama penelitian kualitatif tidak akan lepas dari kegiatan pembukaan akses di lokasi penelitian, yang berfungsi untuk melakukan pendekatan terhadap informan supaya tujuan penulis melakukan penelitian dapat dipahami, diterima, dan bahkan didukung. Artinya untuk menghindari resistensi atau ketidakpahaman, salah persepsi dan penolakan oleh pihak informan di lokasi penelitian.

Sehingga pembukaan akses dalam penelitian ini dijadikan langkah awal untuk studi pendahuluan dengan menggunakan strategi yaitu: (1) Melalui komunikasi 
informal terlebih dahulu kepada informan kunci sebagai pembuka akses ke lokasi penelitian. Komunikasi informal ini dengan melakukan pendekatan, melobi, dan mempersuasi serta menjelaskan tujuan penelitian kepada informan kunci yang sebelumnya belum dikenal akrab dengan peneliti. Informan kunci tersebut sesungguhnya adalah murid yang pernah mengikuti proses belajar-mengajar secara tutorial di Universitas Terbuka pada tahun 2009/2010 di Kelompok belajar (Pokjar) UT Daerah Kemeranjen Kabupaten Banyumas yang berbatasan dengan daerah Kroya Kabupaten Cilacap. Informan kunci tersebut, penulis pilih karena rumah tempat tinggalnya berdekatan dengan lokasi penelitian dan memiliki kerabat di lokasi penelitian. Kemudian penulis sangat membutuhkan informasi tentang lokasi tersebut, mengingat desa Pasuruhan sebagai lokasi penelitian masih dipandang oleh publik luar sangat kurang kondusif, sensitif, atau berbahaya sehingga menimbulkan persepsi yang kurang baik.

(2) Langkah selanjutnya dengan melakukan komunikasi informal dengan meminta kesediaan informan kunci untuk dipertemukan dengan kerabatnya di lokasi penelitian. Sehingga proses pendekatan, melobi dan menegosiasi tujuan kegiatan pemberdayaan masyarakat sekaligus penelitian kepada kerabat informan kunci yang menjadi peserta pemberdayaan. Sekaligus meminta informan kunci untuk dipertemukan dengan Kepala Desa Pasuruhan melalui orang tua (bapaknya) informan kunci yang merupakan teman akrabnya kepala desa tersebut. Maka terjadi lagi komunikasi informal dengan melobi dan mempersuasi bapaknya informan kunci untuk bersedia mempertemukan dengan kepala desa yang merupakan teman akrabnya, supaya pembukaan akses lebih bisa cepat diterima dan lancar.

(3) Ketika melakukan komunikasi informal dengan melakukan pendekatan, melobi, dan negosiasi untuk menjelaskan tujuan kegiatan pemberdayaan masyarakat dan penelitian kepada Kepala Desa Pasuruhan, juga berlangsung suatu komunikasi formal yaitu berdialog dengan saling memperkenalkan diri dengan status profesi atau institusi yang dipresentasikan. Satu pihak penulis memperkenalkan diri sebagai staf pengajar perguruan tinggi (Unsoed) yang memiliki tugas untuk kegiatan pemberdayaan masyarakat dan penelitian. Satu pihak lainnya adalah Kepala Desa (jabatan formal) yang menerima tim pemberdayaan masyarakat dan tim penelitian di lokasi. Kemudian komunikasi formal tertulis juga ditransaksikan berupa surat resmi permohonan izin kegiatan pemberdayaan masyarakat dan penelitian dari institusi perguruan tinggi yang ditandatangani dekan dan stempel fakultas yang diterima kepada kepala desa. Surat resmi yang merupakan komunikasi formal tertulis tersebut kemudian oleh pihak desa di proses atau ditindaklanjuti pengajuan kegiatan tersebut.

(4) Proses komunikasi informal melalui pendekatan dan melobi kemudian dibarengi (diperkuat) oleh komunikasi formal (antar instiusi) melalui surat resmi. Ternyata untuk kegiatan pertama sampai ketiga sebagai suatu rangkaian pemberdayaan masyarakat, komunikasi yang terjalin antara penulis dengan pihak desa dan peserta pemberdayaan sebagai informan penelitian terjadi komunikasi informal, yang lebih cair, akrab, dan intens, tidak formal lagi seperti ketika awal pembukaan akses.

(5) Hal ini membuktikan bahwa pembukaan akses dalam proses penelitian dengan dapat berkomunikasi secara informal dan formal, memiliki peran yang sangat strategis dan menentukan. Karena jika pembukaan akses dengan komunikasi informal dan formal gagal atau tidak berhasil, maka kemungkinan proses penelitian akan mendapat resistensi atau tidak didukung bahkan bisa ditolak, baik oleh informan kunci maupun informan lainnya yang menjadi sasaran penelitian.

Berdasarkan hasil analisis data penelitian tersebut, maka dibuat suatu model komunikasi formal dan informal dalam proses pembukaan akses penelitian seperti pada gambar 1. 


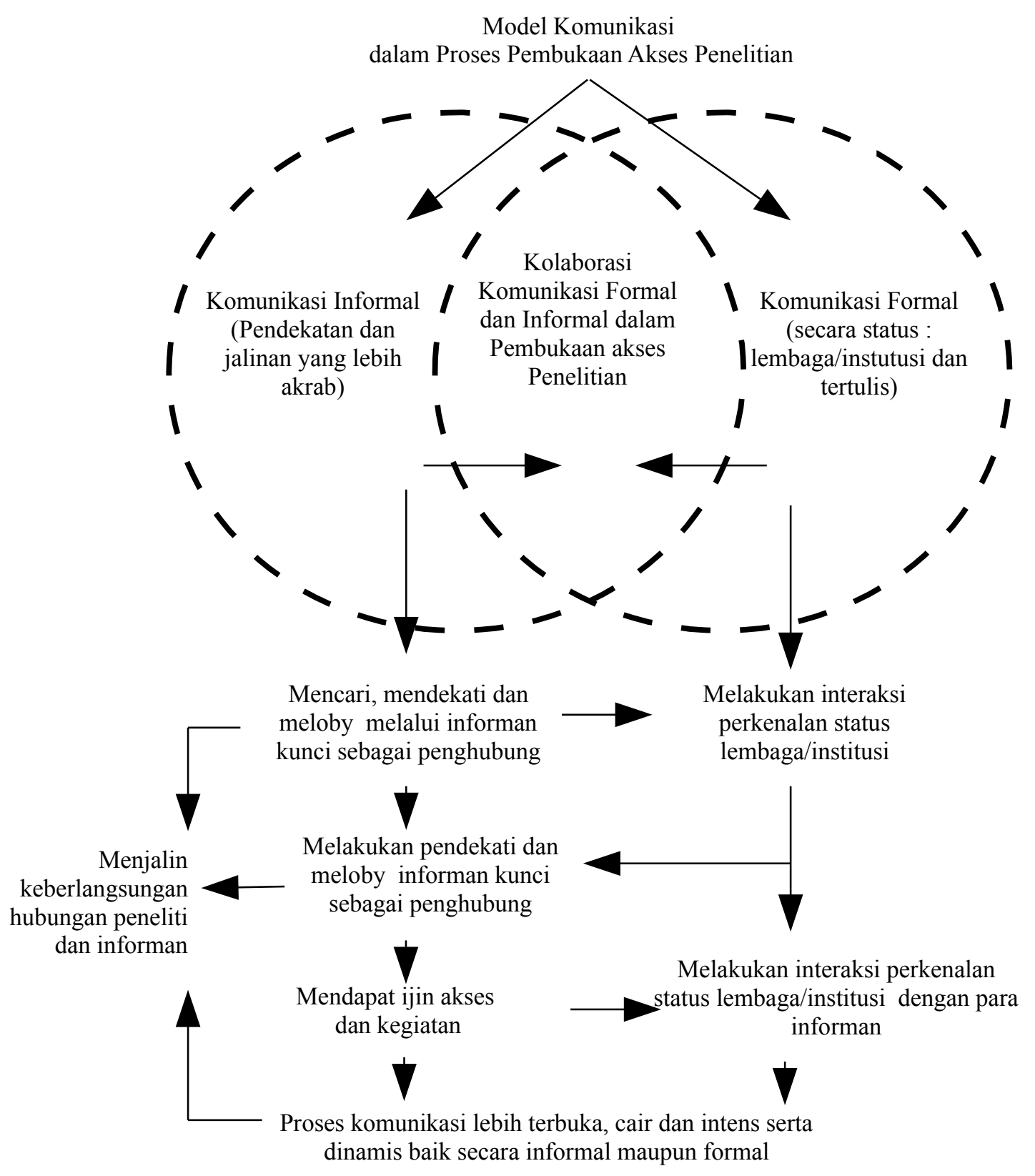

Gambar 1

Model Komunikasi dalam Proses Pembukaan Akses Penelitian

\section{Pembahasan}

Komunikasi Formal dan Informal dalam Proses Penelitian

Proses pembukaan akses ke lokasi penelitian melalui strategi komunikasi informal yaitu melakukan pendekatan, menjelaskan tujuan dan melobi serta negosiasi kepada informan kunci, untuk bisa dibantu dipertemukan kepada informan lainnya yang menjadi subjek penelitian. Kemudian dilakukan komunikasi formal dengan berinteraksi menggunakan atas nama institusi atau lembaga dan surat resmi kepada informan yang juga berposisi memiliki kewenangan formal untuk bisa membantu dan memberikan izin kegiatan penelitian. Setelah terjadi kesamaan pemahaman (mutual understanding), maka akan ada penerimaan dari informan kepada penulis, sehingga bentuk komunikasi informal akan lebih dominan yang dikarenakan sudah akrab dan saling memahami atau menerima. 
Namun dalam proses penelitian, tetap bentuk komunikasi formal akan muncul lagi yaitu pertama, ketika berlangsung proses kegiatan Focuss Group Discussion (FGD), hasil analisis penelitiannya yaitu:

(1) Pada pelaksanaan FGD I yaitu untuk mengidentifikasi masalah dan potensi, di mana para informan sebagai peserta FGD digabung dari semua kelompok usaha yaitu pengurus koperasi, kelompok tani, dan kelompok usaha kecil. Komunikasi formal terjadi yaitu: (1) Ketika dimulai kegiatan pemberdayaan dengan adanya seremonial acara pembukaan seperti sambutan-sambutan dan penjelasan rangkaian kegiatan pemberdayaan. (2) Kegiatan sesi identifikasi masalah dan potensi yang dipimpin seorang moderator yang mengeksplorasi para informan sebagai pesert FGD. Kemudian para informanpun melakukan komunikasi secara formal, yang ditandai dengan gaya komunikasi yang sudah disiapkan secara tertulis inti yang mau disampaikan dan sistematis. (3) Kemudian yang berbicara dalam forum FGD, adalah perwakilan dari kelompok usaha secara struktur formal organisasi, seperti oleh ketua dan wakil yang mengatasnamakan perwakilan organisasi. Sedangkan anggota atau pengurus selain ketua, tidak ada yang berkomunikasi karena sudah terwakili atau menyerahkan kepada ketua kelompok. Hal ini disebabkan para kelompok usaha sebagai informan atau peserta FGD, sepertinya sudah disepakati oleh setiap kelompok usaha kalau yang akan berbicara atau menyampaikan pendapat adalah ketua atau wakil ketua.

Sehingga pada kegiatan FGD I berlangsung, lebih dominan komunikasi formal yang terjadi, artinya komunikasi hanya satu arah dan terpusat yaitu dari moderator FGD dengan salah satu delegasi kelompok usaha yaitu ketua atau wakil ketua kelompok. Kecuali ketika sebelum kegiatan FGD I, memang terjadi komunikasi formal seperti pada kegiatan pengecekan dan pengisian daftar hadir peserta, serta rehat (coffe break) sebelum kegiatan FGD dimulai atau ketika waktu istirahat dan makan siang ketika kegiatan FGD dimulai lagi, yaitu dengan berkenalan dan bercengkerama. Hal tersebut masuk dalam kategori melakukan teknik wawancara dalam proses penelitian yang terjadi tidak terstruktur, lebih bebas dan fleksibel. Sehingga komunikasi formal kembali terjadi lagi ketika kegiatan FGD berlangung.

(2) Pada pelaksanaan FGD II untuk menganalisis hasil FGD I yaitu identifikasi masalah dan potensi bahwa komunikasi formal masih terjadi, namun sudah tidak lagi satu arah didominasi ketua atau wakil ketua kelompok yang mewakili kelompoknya dengan moderator dan instruktur. Karena pelaksanaan FGD II sudah dipisahkan dalam bentuk kelompok khusus (cluster) yaitu FGD khusus kelompok koperasi, FGD khusus kelompok-kelompok tani dan FGD khusus kelompok-kelompok usaha. Adapun analisisnya sebagai berikut: (1) Sudah mulai tidak lagi didominasi ketua atau wakil ketua kelompok dalam diskusi atau berpendapat, seperti para peserta yang memiliki jabatan sekretaris dan bendahara atau pengurus lain selain, sudah mulai ikut berpendapat, walau dengan pembahasan hanya menambahkan. Hal tersebut dikarenakan, selain sudah dalam bentuk diskusi kelompok khusus, artinya FGD II memang setiap peserta dalam kelompok diminta untuk dapat berpendapat atau berdiskusi dan berpartisipasi secara aktif untuk ikut sama-sama memecahkan masalah yang teridentifikasi dalam FGD I yang dikoordinir oleh ketua kelompok. Kemudain moderator atau instruktur juga sudah langsung menanyakan atau meminta tanggapan langsung kepada setiap peserta FGD kelompok khusus. (2) Kemudian lebih mudah dan efektif dalam pengelolaan forum atau peserta (informan) dalam FGD kelompok khusus lebih sedikit jumlahnya. Hal tersebut bisa disebut memiliki struktur jaringan komunikasi jenis lingkaran, di mana semua anggota posisinya sama memiliki wewenang atau kekuatan yang sama untuk memengaruhi (berpendapat) dan berkomunikasi dengan sesama anggota (DeVito, 2011). (3) Kemudian para peserta di dalam kelompoknya mulai saling berinteraksi dengan menggunakan bahasa informal, artinya tidak berdiam diri secara pasif yang hanya mendengarkan saja. Namun peserta 
kelompok juga sudah tidak kaku lagi (sungkan) atau menjadi lebih cair, akrab, humoris, dan dinamis. Sehingga komunikasi tidak lagi satu arah dari ketua atau wakil ketua kepada moderator atau instruktur tetapi sudah dua arah. Hasilnya adalah selain analisis atas idetifikasi masalah dan potensi, juga sudah mulai membuat rancangan untuk membuat model pemberdayaan.

Sehingga komunikasi informal selain sudah terjadi ketika sebelum dan masa isirahat atau setelah kegaitan FGD, juga sudah berlangsung dalam proses FGD II pada situasi formal khususnya dilakukan antaranggota kelompok.

(3) Pelaksanaan FGD III yaitu untuk merancang pemodelan pemberdayaan, yang berdasarkan hasil dari FGD II. Peserta atau informan dari kelompok khusus sudah digabungkan lagi secara bersama-sama dengan kelompok khusus lainnya. Setiap kelompok usaha, diberikan kesempatan untuk mempresentasikan hasil FGD II yaitu analisis masalah dan potensi serta perancangan model pemberdayaan. Kemudian ditanggapi, diberikan masukan atau dikritik oleh peserta satu kelompok usaha atau oleh kelompok usaha lainnya. Sehingga pola komunikasi formal yang terjadi lebih dinamis dan partisipatif, atau struktur jaringan komunikasi bersifat semua lingkaran (bintang). Artinya semua peserta (informan) memiliki kesempatan dan kekuatan yang sama untuk berpendapat dan memengaruhi anggota lainnya dan keputusan (DeVito, 2011).

Komunikasi informal dalam proses FGD III lebih dominan sekalipun dalam keadaan atau situasi formal. Hal ini dikarenakan: (1) Komunikasi yang terjadi tidak lagi dibatasi oleh hanya ketua atau wakil ketua sebagai juru bicara atau perwakilan kelompok, tetapi anggota atau semua peserta FGD memiliki kesempatan secara terbuka. (2) Moderator dan instruktur juga memberikan kesempatan seluas-luasnya untuk sumbang saran atas rancangan yang dipresentasikan oleh salah satu kelompok. (3) Para peserta FGD sudah sangat saling akrab, cair, dan beradaptasi karena sudah terbiasa dengan kegiatan FGD yang telah dialami sebelumnya. Sehingga dalam berkomunikasi untuk mengeluarkan berpendapat dan kritiknya sudah tidak sungkan dan kaku lagi, serta terbatasi oleh struktur dalam kelompoknya. (4) Sehingga komunikasi informal secara nyata berbarengan dalam situasi komunikasi formal pada FGD III. (5) Peserta sebagai informan ketika sebelum, sedang, dan sesudah kegiatan FGD III, lebih proaktif dan komunikatif secara terbuka dengan peserta lain dan penulis. Hal ini seperti menyapa dan tersenyum duluan, aktif bertanya dan antusias dalam menanggapi interaksi.

Kedua, pada tahap wawancara dalam proses penelitian, lebih ditekankan pada komunikasi informal, melalui pendekatan yang lebih humanis, akrab, dan persuasif. Wawancara dengan teknik komunikasi informal ini dilakukan dengan para peserta kegiatan FGD ataupun pihak lainnya seperti, Kepala Desa, Perangkat Desa, Kepala Dusun, dan anggota kelompok usaha. Pelaksanaan wawancara dilakukan dengan cara :

1. Ketika sedang melakukan proses pembukaan akses untuk pendekatan, proses izin kegiatan, mengundang kegiatan FGD serta melakukan persiapan FGD.

2. Wawancara dilakukan ketika sedang proses pelaksanaan FGD yaitu di awal kegiatan sebelum dimulai, ketika rehat, dan setelah kegiatan FGD.

3. Wawancara juga dilakukan ketika proses kegiatan observasi atau kunjungan ke tempat usaha para peserta seperti kegiatan kunjungan ke tempat kelompok usaha dan ke tempat studi banding.

Ketiga, pelaksanaan penelitian juga tidak lepas dari kegiatan observasi atau pengamatan secara langsung khususnya bersamaan ketika melakukan wawancara mendalam, khususnya pada kegiatan kunjungan ke tempat kelompok usaha dan ketika melakukan studi banding.

Pada proses wawancara dan observasi di lapangan khususnya ketika kunjungan ke tempat kelompok usaha, lebih dipergunakan komunikasi informal karena: (1) Peserta pemberdayaan sebagai informan telah saling kenal dan akrab termasuk dengan penulis 
sehingga lebih cair ketika proses kegiatan FGD yang memungkinkan melakukan wawancara dengan komunikasi informal. (2) Kegiatan wawancara memanfaatkan situasi ketika sebelum, masa rehat, dan sesudah kegiatan FGD, sehingga informan merasa tidak seperti sedang di wawancara tetapi seperti berdialog atau mengobrol biasa. Sehingga komunikasi informal lebih tepat dan efektif.

(3) Komunikasi informal dalam wawancara juga dilakukan ketika sedang menuju, melakukan, dan setelah kegiatan kunjungan ke tempat kelompok usaha serta kunjungan.
Kecuali dalam mengawali dalam kegiatan resmi kunjungan atau studi banding, terlebih dahulu dengan komunikasi formal, seperti memperkenalkan diri, menjelaskan tujuan kegiatan kunjungan dan menyerahkan surat izin atau permohonan kunjungan serta sambutan-sambutan formal ketika mengawali kunjungan. Berdasarkan analisis komunikasi formal dan informal dalam proses penelitian kegiatan pemberdayaan masyarakat, maka dapat dibuat model, supaya lebih memperjelas hasil analisis, seperti pada gambar 2.

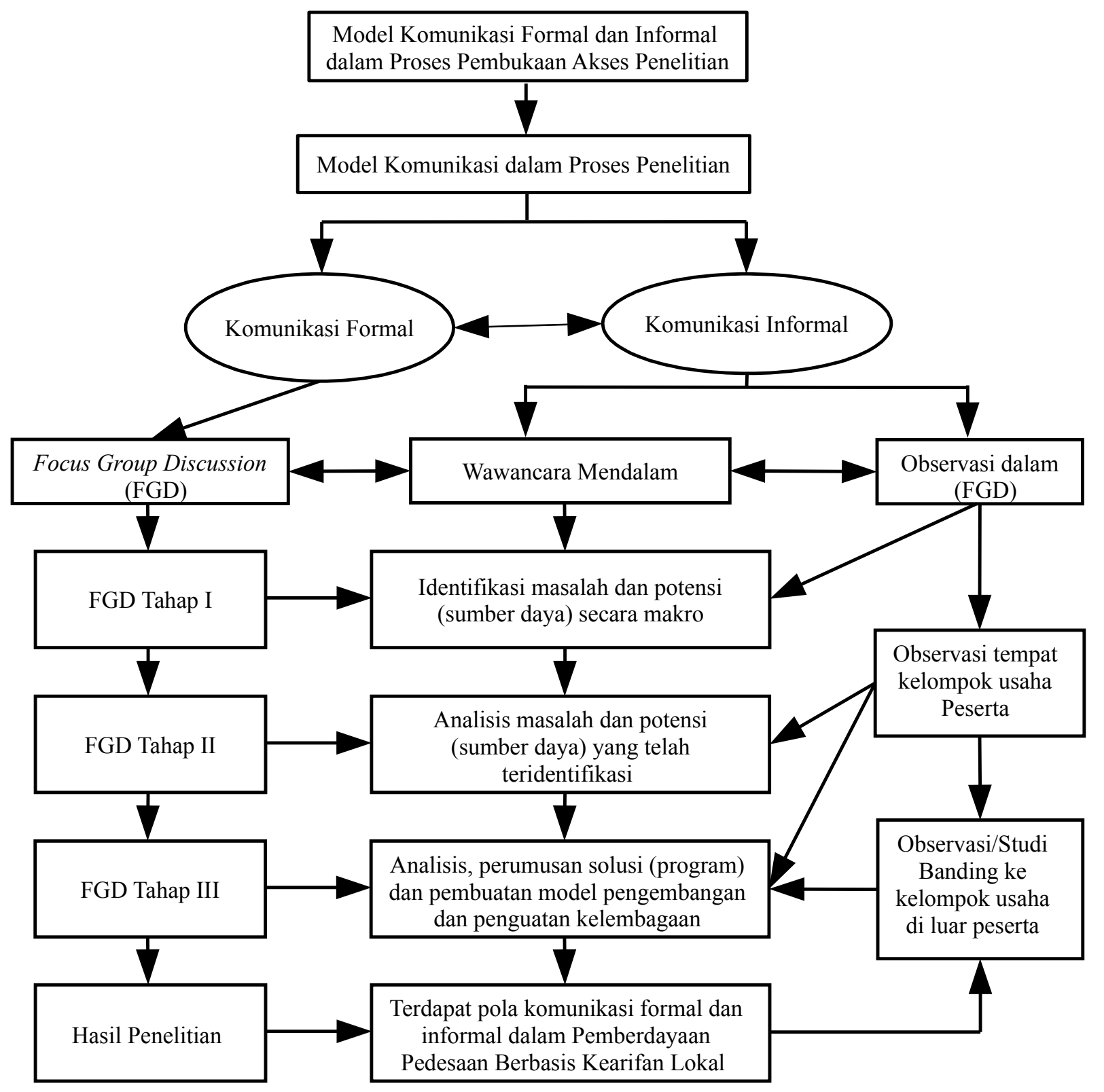

Gambar 2

Model Komunikasi Formal dan Informal dalam Proses Penelitian 


\section{Komunikasi Formal dan Informal pada Pelaksanaan Model Pemberdayaan Masyarakat}

Setelah melalui serangkaian proses penelitian seperti pembukaan akses, pendekatan, wawancara mendalam, observasi, dan dialog dalam kegiatan Focus Group Discussion (FGD) yaitu pelaksanaan model kegiatan pemberdayaan masyarakat, adapun tahapan implementasinya sebagai berikut :

Pertama, teknik triangulasi. Penulis sebelum mengimplementasikan model pemberdayaan masyarakat, dengan melakukan triangulasi atas hasil FGD sebagai proses komunikasi formal dengan menggunakan teknik wawancara mendalam dan observasi kepada informan, baik sebagai peserta pemberdayaan, maupun kepada para pemangku kepentingan (stakeholders) seperti Kepala Desa, Perangkat Desa, Kepala Dusun (Kadus), tokoh masyarakat, pelaku usaha, aktivis, pengurus Ormas, akademisi (teman sejawat) dan lain sebagainya. Kegiatan triangulasi ini sangat penting dalam proses penelitian kualitatif untuk mendapat keabsahan atau validitas data dan hasil penelitian. Sebagaiman menurut Creswell (2010) dalam validitas data kualitatif salah satunya dengan melakukan triangulasi (triangulate) yaitu sumber data yang berbeda kemudian diperiksa bukti-bukti yang berasal dari sumber-sumber tersebut untuk membangun justifikasi tema-tema secara koheren (saling berkaitan).

Pelaksanaan model pemberdayaan masyarakat merupakan hasil dari penelitian sekaligus juga hasil dari kesepakatan bersama dari proses komunikasi dialogis partisipatif khususnya dalam FGD sebagai komunikasi formal dan teknik triangulasi sebagai proses konstruksi keabsahan data dan hasil penelitian kualitatif. Karena karakteristik penelitian kualitatif menurut Muljono (2012) salah satunya tentang hasil penelitian harus dirundingkan dan disepakati bersama, dikarenakan realitas subjek (informan) yang diteliti, hasil penelitian bergantung pada hakikat dan kualitas hubungan antara penulis dan informan, kemudian menjadi lebih baik jika dilakukan verifikasi serta dikonfirmasi dengan informan.

Kedua, tahapan pendekatan dan perizinan, dengan melakukan komunikasi informal dan formal. Melakukan pendekatan kembali dengan komunikasi informal di lokasi penelitian terutama kepada Kepala Desa untuk mendapat dukungan dan izin kegiatan sekaligus mengajukan surat resmi sebagai bentuk komunikasi formal tertulis berupa permohonan izin kegiatan, tempat kegiatan dan permohonan undangan untuk peserta kegiatan pelaksanaan pemberdayaan masyarakat. Penulis setelah mendapat izin kegiatan dan kesepakatan jadwal pelaksanaan pemberdayaan masyarakat dari Kepala Desa, selanjutnya melakukan pendekatan dan sosialisasi kepada para peserta pelaksanaan pemberdayaan yaitu pada kelompok koperasi, kelompok usaha tani, kelompok usaha kecil. Pada tahap pendekatan, rencana pelaksanaan dan sosialisasi kegiatan pemberdayaan masyarakat, komunikasi informal lebih dominan dibandingkan dengan komunikasi formal yang dilakukan oleh penulis kepada Kepala Desa, hal ini dikarenakan kedekatan dan keakraban penulis dengan informan atau peserta pemberdayaan sudah terjalin serta terbangun cukup lama yaitu ketika proses penelitian sebelumnya. Sehingga proses pendekatan dan rencana pelaksanaan pemberdayaan masyarakat juga lebih mudah dilaksanakan. Maka menjadi hal yang sangat penting dan mendukung dalam suatu proses penelitian kualitatif adanya proses pembukaan akses, pendekatan dan menjalin kedekatan antara penulis dengan yang diteliti, sehingga penulis ikut berbaur, beradaptasi dan menjadi bagian dari subjek yang diteliti. Hal ini yang tidak didapatkan di dalam penelitian kuantitatif, di mana ada jarak antara penulis dengan responden untuk menjaga objektivitas.

Ketiga, tahapan sosialisasi model pemberdayaan masyarakat, komunikasi formal lebih dominan dalam kegiatan Focus Group Discussion (FGD) berupa penjelasan dari penulis dan tim ahli kepada peserta pemberdayaan tentang program pemberdayaan yang akan dilaksanakan yaitu penyuluhan, pelatihan, dan pendampingan. Komunikasi formal juga berlangsung dalam 
proses dialogis partisipatif dari peserta dalam sosialisasi model pemberdayaan. Namun ketika sebelum dan sesudah kegiatan sosialisasi dilaksanakan, komunikasi informal dilakukan oleh penulis dan peserta pemberdayaan dengan saling menyapa, bertanya, dan terjalin dialog yang intens, lebih terbuka serta harmonis.

Keempat, tahapan penyuluhan kegiatan pemberdayaan masyarakat, komunikasi formal juga masih dominan, dikarenakan para penyuluh atau instruktur menjelaskan materi dan membutuhkan perhatian yang serius dari peserta. Kemudian peserta penyuluhan juga tidak pernah memotong untuk bertanya atau menanggapi pemaparan atau penjelasan penyuluh. Kecuali ketika penyuluh atau instruktur membuka kesempatan untuk tanya jawab, maka peserta pemberdayaan baru bisa berargumen dan bertanya kepada penyuluh.

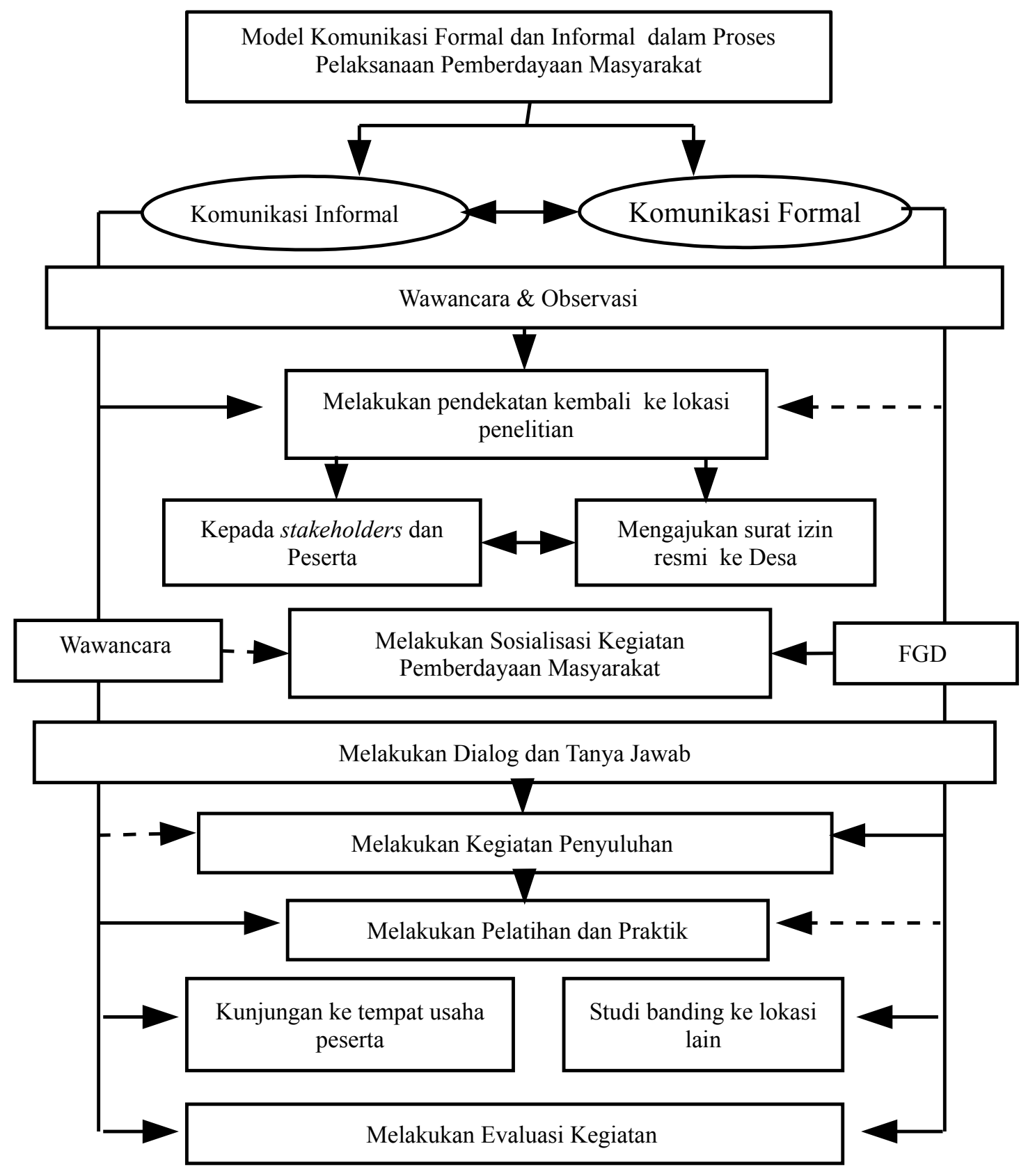

Gambar 3

Model Komunikasi Formal dan Informal dalam Kegiatan Pemberdayaan 
Kelima, tahapan kegiatan pelatihan dan praktik kegiatan pemberdayaan masyarakat, komunikasi informal lebih dominan dengan melalui teknik wawancara mendalam dan observasi. Karena para penyuluh atau instruktur menekankan pada partisapasi langsung dan kerjasama dengan peserta atau kelompok dan antarpeserta (kelompok). Komunikasi informal semakin intensif dan dinamis, ketika kegiatan pelatihan dan praktik atau simulasi kegiatan contoh dalam pelatihan manajemen koperasi seperti membuat struktur kepengurusan, tugas pokok dan fungsi pengurus, membuat Anggaran Dasar dan Anggaran Rumah Tangga Koperasi, Rencana Kerja Koperasi, manajemen keuangan dan simulasi rapat pengurus serta rapat anggota tahunan.

Keenam, tahap kegiatan kunjungan dan studi banding. Komunikasi informal lebih dominan perannya melalui teknik wawancara mendalam dan observasi ketika pelaksanaan kegiatan kunjungan ke tempat kelompok usaha para peserta pemberdayaan masyarakat. Penulis, penyuluh, atau instruktur dan terutama peserta lebih intens dan terbuka dalam melakukan dialog, tanya jawab, dan menceritakan keadaan usaha yang dijalankan. Sedangkan tahap kegiatan studi banding para peserta pemberdayaan di lokasi lain atau di luar daerah para peserta pemberdayaan, seperti studi banding untuk mencari pengalaman ke Koperasi Senkuko Cilongok Kabupaten Banyumas sebagai koperasi berprestasi peringkat ke-3 tingkat Provinsi. Studi banding berlangsung dengan komunikasi formal antara penulis dan penyuluh atau instruktur sebagai fasilitator yang mempertemukan dan memperkenalkan para peserta pemberdayaan dengan pengurus Koperasi Senkuko. Dialog dalam komunikasi formal juga terjadi dalam kegiatan tanya jawab dan diskusi antara peserta pemberdayaan dengan pengurus Koperasi Senkuko. Namun ketika agenda terakhir berupa kegiatan kunjungan ke fasilitas kantor dan tempat usaha yang dimiliki Koperasi Senkuko, dialog dalam komunikasi informal lebih dominan.

Ketujuh, tahap evaluasi kegiatan pemberdayaan masyarakat, komunikasi formal terjadi dalam pembukaan dan prolog awal dari penulis dan pihak desa akan tetapi pada waktu penyampaian evaluasi berupa masukan dan kritik dari peserta kegiatan, komunikasi informal mulai berlangsung. Hal tersebut dikarenakan penulis memberikan kesempatan untuk peserta mengevaluasi kegiatan dengan menyampaikan aspirasi dan argumennya baik kritik, saran, dan harapannya, tanpa ada pembelaan dari pihak penulis. Keakraban dan kedekatan semakin kuat terasa ketika peserta mengharapkan keberlanjutan kegiatan pemberdayaan masyarakat dan program pendampingan.

Adapun model komunikasi formal dan informal dalam proses pelaksanaan kegiatan pemberdayaan masyarakat seperti pada gambar 3 .

\section{PENUTUP}

\section{Simpulan}

Hasil penelitian ini, menjelaskan fungsi komunikasi formal dan informal yang sangat penting dan tidak bisa terpisahkan dalam suatu poses penelitian, terutama dalam penelitian kualitatif.

Komunikasi formal tidak bisa dipisahkan dari komunikasi informal dalam proses penelitian, artinya keduanya sangat penting dan saling melengkapi. Sehingga dengan melakukan komunikasi informal terlebih dahulu untuk membuka akses penelitian, melakukan pendekatan, penjelasan tujuan dan lobi terhadap informan kunci dan informan lainnya. Sedangkan komunikasi formal dilakukan setelah akses terbuka dan dalam proses kegiatan formal untuk mempertegas suatu tujuan kegiatan. Kegagalan dalam proses komunikasi informal, bisa membuat proses penelitian dengan pendekatan kualitatif, akan mengakibatkan resistensi, kurang mendapat dukungan, curiga, bahkan bisa terjadi penolakan dari informan penelitian.

$$
\text { Komunikasi formal memiliki }
$$

keutamaan seperti terstruktur atau sistematis, fokus, dan lebih efektif serta jelas pada tujuan berkomunikasi. Kemudian interaksi didasari 
oleh interaksi simbolik status atas nama institusi atau lembaga yang dipresentasikan oleh masing-masing pelaku komunikasi. Sedangkan komunikasi informal memiliki karakteristik seperti tidak terstruktur atau sistematis sehingga proses komunikasi lebih bebas atau tidak kaku artinya komunikasi (dialog) bisa berlangsung lama, namun pembahasan bisa saja menjadi melebar atau tidak fokus. Lebih mengutamakan keakraban atau menjalin hubungan yang intens.

Komunikasi informal dan formal juga berlangsung ketika proses pelaksanaan kegiatan model pemberdayaan masyarakat sebagai implementasi hasil penelitian. komunikasi informal lebih dominan pada tahapan pelaksanaan triangulasi penelitian, pendekatan kembali di lokasi penelitian, sosialisasi kegiatan secara personal, kemudian tahap pelaksanaan pelatihan atau praktik dan kegiatan kunjungan, studi banding serta evaluasi kegiatan. Sedangkan komunikasi formal dominan dalam proses kegiatan sosialisasi kegiatan, penyuluhan, dan studi banding serta evaluasi kegiatan.

Dalam suatu kegiatan seperti pemberdayaan masyarakat, yang harus menjadi perhatian bukan hanya hasil kegiatan, tetapi penting juga mengkaji dari proses kegiatannya yaitu fungsi komunikasi yang diperankan oleh penulis, penyuluh, atau instruktur, dan peserta kegiatan. Karena aspek manfaat, problematika, dan hambatan kegiatan, bisa teridentifikasi serta mendapat solusi dengan meneliti (menganalisis) proses kegiatan melalui kajian komunikasi.

\section{Saran}

Suatu kegiatan pemberdayaan masyarakat harus juga memerhatikan proses kegiatannnya, seperti fungsi dan bentuk komunikasi yang dilakukan para penulis, penyuluh atau instruktur, dan peserta kegiatan sebagai aspek penting, selain hasil kegiatan pemberdayaan. Karena dari aspek komunikasi dapat diidentifikasi problematika dan hambatan yang dirasakan subjek penelitian, serta pada proses kegiatan.

Kemudian pada proses penelitian, terutama kualitatif dan juga untuk penelitian kuantitaif, perlu memerhatikan dan mengutamakan komunikasi informal yang sangat penting dan menentukan dalam proses pelaksanaan serta keberlanjutan penelitian, termasuk bermanfaat untuk pembukaan akses bagi pelaksanaan komunikasi formal. Saran terakhir, bahwa komunikasi informal harus terus dipelihara untuk keberlanjutan jalinan akses dan interaksi antara penulis dan subjek penelitian, walaupun kegiatan pemberdayaan dan penelitian sudah berakhir.

\section{DAFTAR PUSTAKA}

\section{Buku:}

Adi, IR. (2003). Pemberdayaan, Pengembangan Masyarakat Dan Intervensi Komunikasi (Pengantar pada Pemikiran dan Pendekatan Praktis). Jakarta: Fakultas Ekonomi Universitas Indonesia.

Azis, A. (2008). Memahami Fenomena Sosial Melalui Studi Kasus: Di dalam Bungin, Burhan, editor. Analisis Penelitian Kualitatif. Jakarta: Rajawali Pers

Blake RH, Haroldsen EO. (2005). Taksonomi Komunikasi. Bahanan H, penerjemah. Surabaya: Papyrus. Terjemahan dari : $A$ Taxonomy of Concepts is Communication.

Bogdan R, Taylor SJ. (1993). Dasar-Dasar Penelitian Kualitatif. Afandi AK, penerjemah. Surabaya: Usaha Nasional

Denzin, K. Norman and Linclons. Yvonna (2009). Pendahuluan: Memasuki Bidang Penelitian Kualitatif. Dariyanto et al, penterjemah; Denzin, K. Norman and Linclons. Yvonna, editor. Handbook of Qualitative Research.Yogyakarta: Pustaka Pelajar. Terjemahan dari: Handbook of Qualitative Research. 2000. Thousand Oak, California (US) : Sage Publication DeVito, JA. (2011). Komunikasi Antarmanusia. Maulana A, penerjemah. Wahyu YI, Prihantini Y, editor. Tangerang Selatan: Karisma Publishing Group.

Dasgupta, S. (2009). Sonagachi Project: A Case-Study Set India. McPhail TL, 
editor. Development Communication : Reframing The Role of Media. Malden (US), Oxford (GB): Blackwell Publishing Ltd.

Effendy, Onong Uchjana. (2005). Ilmu Komunikasi: Teori dan Praktek. Bandung: Rosdakarya

Herdiansyah, H. (2011). Metodologi Penelitian Kualitatif : untuk Ilmu-Ilmu Sosial. Jakarta : Salemba Humanika

Kriyantono, R. (2006). Tekinik Praktis Riset Komunikasi. Jakarta : Kencana.

Lubis, D. (2010). Komunikasi dan Pembangunan. Di dalam : Hubeis AVS, editor. Dasar-Dasar Komunikasi. Bogor : Sains KPM IPB Pr.

Mardikanto, T. (2010). Konsep-Konsep Pemberdayaan Masyarakat : Acuan Bagi Aparat Birokrasi, Akademisi, Praktisi dan Minat/Permerhati Pemberdayaan Masyarakat, Surakarta : UNS Press.

Milles MB, Huberman AM. (2007). Analisis Data Kualitatif. Penerjemah: Tjetjep Rohendi Rohidi, Jakarta: UI Press.

Mulyana, Deddy. (2005). Ilmu Komunikasi: Suatu Pengantar. Bandung: Rosdakarya.

Nasution, Z. (2009). Komunikasi Pembangunan: Pengenalan Teori dan Penerapannya. Jakarta: Rajawali Pr.

Payne, M. (1997). Modern Social Work Theory. Second Edition, London: McMillan Press Ltd.
Rangkuti, PA. (2011). Komunikasi Pembangunan dan Mekanisasi Pertanian. Bogor: IPB Pers.

Sulistiyani, Ambar Teguh. (2004). Kemitraan dan Model-Model Pemberdayaan' Yogyakarta: Gaya Media.

Syahyuti. (2006). Tiga Puluh Konsep Penting Dalam Pembangunan Pedesaan dan Pertanian : Penjelasan tentang Konsep, Istilah, Teori, Indikator serta Variabel, Jakarta: PT. Bina Rena Pariwara.

\section{Tesis/Laporan Penelitian:}

Muchlis, F. (2009). Analisis Komunikasi Partisipatif dalam Program Pemberdayaan Masyarakat (Studi Kasus pada Implementasi Musyawarah dalam PNPM Mandiri Perdesaan di Desa Teluk Kecamatan Pemayung Kabupaten Batang Hari) [Tesis]. Bogor (ID) : Institut Pertanian Bogor.

Satriani, I. (2011). Komunikasi Partisipatif pada Program Pos Pemberdayaan Keluarga (Studi Kasus di RW 05 Kelurahan Situgede Kecamatan Bogor Barat Kota Bogor) [Tesis] Mayor Komunikasi Pembangunan Pertanian dan Pedesaan. Bogor: Institut Pertanian Bogor.

Suswanto. B. (2011). Model Psikologi Humanistik Pasca Penangkapan Terorisme di Provinsi Jawa Tengah. Purwokerto: LPPM Unsoed. 